\title{
フィンランドの設計専門家と非専門家の \\ 住空間に用いる内装用木材に対する評価構造 \\ EVALUATION STRUCTURE OF FINNISH DESIGN PROFESSIONALS AND LAYMEN ON INTERIOR WOOD FOR LIVING SPACE
}

\author{
坂口大史*，浅倉和真**, 北川啓介***, 坂井文也**** \\ Daishi SAKAGUCHI, Kazuma ASAKURA, Keisuke KITAGAWA \\ and Fumiya SAKAI
}

\begin{abstract}
The evaluation structure of Finnish design professionals and laymen for interior wood were investigated following a previous study. As a result, the tendency of the evaluation structure was clearly divided by the design professionals and laymen in case of Finland. The features of the structure for the professionals were observed as calmness by the condition of grain pattern, added value for space by natural aging and versatility of wood. On the other hand, the features of the structure for the laymen were related to harmony with surroundings by familiarity of wood, modernity by novel color and safety by naturalness of wood. In a future study, a comparative study for the evaluation structure of both J apanese and Finnish design professionals and laymen will be conducted to examine the effective measures for utilization of domestic wood and guideline to design wooden architecture.
\end{abstract}

Keywords : Interior Wood, Living Space, Evaluation Structure, Design Professional, Finland, Evaluation Grid Method 内装用木材, 住空間, 評価構造, 設計専門家, フィンランド, 評価グリッド法

\section{1. 研究の背景と目的}

\section{1 研究の背景}

フィンランドは，国土に占める森林の割合を示す森林率が 70\% を

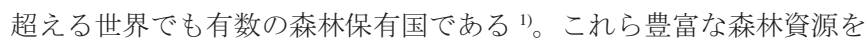
活かして，製紙業や木材業から建設業に至るまで多種多様な分野に おいて木材を利用してきた。とりわけ，フィンランドの建築分野で は，小規模の一戸建て住宅や集合住宅から，大規模な公共建築など 規模の異なる建築物において国産の木材が活用されてきた 2)314。ま た，近年では，フィンランドは構造材としてCLT の利用や建築物の 内装木質化などにも積極的に取り組んでおり, 先進的な木造・木質 建築の実現において一定の成果を収めてきた国のひとつである 5) 6)

本稿に関わる一連の研究として,筆者らは空間の設計専門家（以下， 専門家）と非専門家を対象に, 内装用木材を用いた個別インタビュー を行うことで, 木材に対する認知構造と潜在的選択要因について研 究してきた7)。この研究では, どのような観点から木材を認識してい るのかを示す認知構造を分析することで，木材を空間に用いる際の 潜在的選択要因を明らかにした。また, 前稿 ${ }^{81}$ では, 日本の専門家 と非専門家を対象として, 内装用木材を用いた評価グリッド法によ る個別インタビューを行うことで, 内装用木材に対する評価構造を
抽出した。さらに，抽出した評価構造を類型化して分析することに より，被験者の各属性における評価の傾向や空間設計に関する専門 性による評価構造への影響を考察した。

\section{2 研究の目的}

本稿では，筆者らがこれまで取り組んできた既往研究718)の継続的 な研究として, フィンランドの専門家と非専門家を対象に, 内装用 木材を用いた評価グリッド法による個別インタビューを行う。さら に，個別インタビューから得られた評価構造を分析することにより， フィンランドの専門家と非専門家の各属性における内装用木材に対 する評価の傾向，建築やインテリアに関する専門性が評価構造に及 ぼす影響を明らかにすることを目的とする。

本稿に続く発展的な研究として, 前稿8)で得られた日本の専門家 と非専門家の内装用木材に対する評価構造の分析結果と本稿の結果 の比較考察を行う予定である。これにより，日本とフィンランドそ れぞれの国の専門家と非専門家の内装用木材に対寸る評価構造にお ける共通点や相違点を明らかにし，建築や都市においてより良い木 質空間を設計するための指針に関わる知見を体系的に把握する。さ らに, 比較考察から得られる知見は, 今後, 日本において国産材の 有効活用を進める上での指針に関する基礎的な知見にもなりえる。
名古屋工業大学大学院工学研究科 博士後期課程 日本福祉大学健康科学部福祉工学科 助教 ·修士 (工学)

** (株)奥村組 修士 (工学)

*** 名古屋工業大学大学院つくり領域 准教授・博士 (工学)

**** 国土交通省中部地方整備局木曽川上流河川事務所 修士(工学)
Doctoral Candidate Graduate School of Engineering Nagoya Institute of Technology: Assist. Prof., Faculty of Health Science, Department of Human Care Engineering, Nihon Fukushi Univ., Master of Engineering

Okumura Corporation, Master of Engineering

Assoc. Prof., Tsukuri College, Graduate School of Engineering, Nagoya Institute of Technology, Doctor of Engineering

Kisogawa-Joryu River Office, Chubu Regional Bureau, Ministry of Land,

Infrastructure and Transport, Master of Engineering 


\section{2. 研究対象と研究方法}

前稿 ${ }^{8)}$ と同様に, 3 年以上の実務経験を有する建築家とインテリア デザイナーを専門家と定義する。続いて, 学部生もしくは大学院生 として大学に所属寸る学生と一般的な仕事に従事している人（以下, 一般人）を非専門家注1) と定義する。最終的に，フィンランドの専門 家と非専門家共に年齢，性別の偏りを考慮し，本実験における被験 者 40 人を選定した（表 1 )。さらに，前稿 8 ) と同様に計 12 種類の木 材注2)を個別インタビューに用いた（表 2 ）。

研究の流れとして, 前稿 ${ }^{8)}$ と同様に 12 種類の木材エレメントを用 いた評価グリッド法による個別インタビューを行った。評価グリッ ド法は，一般的なユーザーのニーズを把握するために使用される手 法であり，本稿を含めた一連の研究 718) における非専門家は，この場 合の一般的なユーザーにあたる。その一方で，専門家は一般的なユー ザーではないが，空間利用における木材を対象とした場合，木材を 使用する設計側のユーザーと捉えることができる。よって，本稿や 前稿 ${ }^{81}$ に評価グリッド法を用いることで，空間を使用する非専門家と 木材を空間設計に用いる専門家双方のニーズが抽出できると考えた。

個別インタビューにおける共通の教示として，専門家は「被験者 自身が，設計者として住空間の設計に木材を用いる場合」，非専門家 は「被験者自身が，居住者として住空間に住む場合」を想定注3)した 上で，各木材を「住空間に用いる際の好み」によって 5 段階に分類 するよう指示した。続いて，好みによる各分類の判断理由を聞くこ とで評価項目の抽出を行い, 抽出した各評価項目からラダーリング を繰り返し行うことで，被験者それぞれの評価構造を得た注4)

以下に，本稿における研究の流れを段階的に示寸。

1）住空間に用いる際の好みにより木材を 5 段階に分ける。次に, 好み 4 位対 5 位， 3 位対 4 位以下〜 1 位対 2 位以下まで，それぞれ の好办の判断理由を尋称, 被験者毎の評価項目を抽出寸る。

2）次に, 各評価項目に対して, ラダーリングを行うことで上位項目, 下位項目を誘導し, 評価構造を階層的に把握する。続いて, 抽出 した評価項目を意味の内容や類似性により分類する。これら分類 した評価項目毎に指摘回数を集計注5) してコレスポンデンス分析を 行うことで, 被験者が木材の評価において指摘した評価項目から， 各属性における木材に対する評価の傾向や着眼点を把握する。

3）個人差を考慮しながら評価構造を分析するため，評価項目を用い て数量化III類分析とクラスター分析を行い，同じ評価傾向をもつ被 験者をグループ化することで評価構造の類型化を行う。続いて，各 クラスターにおける項目間の繋がりを考慮しながら，評価構造の特 徵を階層的に考察する。さらに，得られた評価構造における専門性 の影響を考慮して専門家と非専門家の共通点や相違点を分析する。

4）上記のクラスター内にみられる被験者の個人差や専門性を考慮 した分析の結果に基づき，結論にまとめる。

\section{3. 評価項目の分類と評価の傾向}

\section{1 評価項目の分類と指摘回数}

評価項目について,前稿 8) と同様の手順により項目を統一した結果, 項目に対する指摘回数の合計は 1356 回であった注6)。また，それらを 分類した結果, 大分類として 7 種, 小分類として 33 種を得た（表 3 )。 専門家における指摘回数からみる評価の傾向として,木材の $\{$ 形状 $\}$ や \{加工\} の指摘回数が多いことから，木目の形状や表面の加工度
表 1 被験者の属性

\begin{tabular}{|c|c|c|c|c|}
\hline 属性 & & 専門家 & & \\
\hline 年齢 & 建築家 & インテリアデザイナー & 学生 & 一般人 \\
\hline 20 代 & 0人 $(0$ 人) & 0人 $(0$ 人) & 10人 (5人) & 0人 (0人) \\
\hline 30 代 & 3人 (2人) & 3人 (2人) & 0人 (0人) & 4人 (3人) \\
\hline 40 代 & 4人 (2人) & 4人 (3人) & 0人 (0人) & 4人 (2人) \\
\hline 50 代 & 3人 (1人) & 3人 (1人) & 0人 $(0$ 人) & 2人(1人) \\
\hline 計 & 10 人 (5人) & 10人 $(6$ 人) & 10人 (5人) & 10人 (6人) \\
\hline
\end{tabular}

※括弧内の数字は全体における女性の数を示す。

表 2 調査に使用した木材エレメント

\begin{tabular}{|l|l|}
\hline \multicolumn{1}{|c|}{ 樹種名 (加工の種類) } & \multicolumn{1}{c|}{ 樹種名（加工の種類） } \\
\hline 杉材白太 (無垢) & パイン材 (無垢) \\
\hline 杉材白太 (ワックス仕上げ) & パイン材 (ワックス仕上げ) \\
\hline 杉材白太 (オイル仕上げ) & パイン材 (オイル仕上げ) \\
\hline 杉材赤身 (無垢) & スプルース材 (無垢) \\
\hline 杉材赤身 (ワックス仕上げ) & スプルース材 (ワックス上げ) \\
\hline 杉材赤身 (オイル仕上げ) & スプルース材 (オイル仕上げ) \\
\hline
\end{tabular}

\section{表 3 評価項目の分類と指摘回数}

\begin{tabular}{|c|c|c|c|c|c|c|c|}
\hline \multicolumn{2}{|c|}{ 分類 } & 評価項目 & \multicolumn{2}{|c|}{ 専門家 } & \multicolumn{2}{|c|}{ 非専門家 } & \multirow{2}{*}{ 計 } \\
\hline 大分類 & 小分類 & 発言例 & 建築家 & 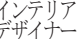 & 学生 & 一般人 & \\
\hline \multirow{6}{*}{ 【色】 } & $\{$ 色相 $\}$ & 黄系の色, 茶系の色 & 11 & 19 & 22 & 16 & 68 \\
\hline & $\{$ 明度 & 明るい色, 暗い色 & 22 & 18 & 18 & 17 & 75 \\
\hline & $\{$ 彩度 $\}$ & 強い色調 & 6 & 4 & 1 & 5 & 16 \\
\hline & $\{$ 配色\} & 色の組合せ & 3 & 5 & 8 & 2 & 18 \\
\hline & $\{$ 印象 $\}$ & 暖かい色，シンプルな色 & 21 & 29 & 24 & 22 & 96 \\
\hline & $\{$ 価值 $\}$ & 高価な色，美しい色 & 3 & 4 & 0 & 0 & 7 \\
\hline \multirow{6}{*}{ 【模様】 } & $\{$ 色相 $\}$ & 木目が茶色 & 1 & 2 & 0 & 1 & 4 \\
\hline & $\{$ 密度 $\}$ & 規則的な木目 & 11 & 9 & 10 & 8 & 38 \\
\hline & $\{$ 形状 $\}$ & 曲線的な木目 & 11 & 11 & 2 & 5 & 29 \\
\hline & $\{$ 明瞭\} & はっきりとした木目 & 5 & 11 & 2 & 5 & 23 \\
\hline & $\{$ 印象\} & 馴染みのある木目 & 12 & 19 & 5 & 6 & 42 \\
\hline & $\{$ 価値 $\}$ & 特有の木目 & 0 & 4 & 3 & 1 & 8 \\
\hline \multirow{4}{*}{ 【表面】 } & 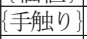 & 滑らかな，平らな & 3 & 6 & 1 & 5 & 15 \\
\hline & $\{$ 加工\} & 加工度合, 無加工の & 22 & 15 & 7 & 12 & 56 \\
\hline & $\{$ 光沢\} & 艶のない & 4 & 3 & 0 & 5 & 12 \\
\hline & $\{$ 印象\} & 清潔な表面 & 6 & 5 & 3 & 1 & 15 \\
\hline \multirow{2}{*}{ 【香気】 } & $\{$ 強弱 $\}$ & 強いにおい & 1 & 1 & 0 & 1 & 3 \\
\hline & $\{$ 印象 $\}$ & 自然なにおい & 1 & 3 & 0 & 1 & 5 \\
\hline \multirow{10}{*}{ 【特質】 } & $\{$ 重量\} & 重い & 9 & 4 & 8 & 8 & 29 \\
\hline & $\{$ 強度 $\}$ & 強度のある, 柔らかい & 9 & 6 & 2 & 2 & 19 \\
\hline & $\{$ 汎用\} & 装飾し易い & 7 & 4 & 3 & 4 & 18 \\
\hline & $\{$ 応用 $\}$ & 家具との組合せ & 10 & 12 & 2 & 1 & 25 \\
\hline & $\{$ 実用\} & 使用しやすい & 8 & 2 & 3 & 0 & 13 \\
\hline & $\{$ 用途\} & 天井に適した & 6 & 4 & 1 & 3 & 14 \\
\hline & $\{$ 品質\} & 質の高い，信頼できる & 19 & 18 & 6 & 10 & 53 \\
\hline & $\{$ 産地\} & 地元由来の & 0 & 4 & 0 & 3 & 7 \\
\hline & $\{$ 樹種\} & 松の木 & 2 & 0 & 0 & 0 & 2 \\
\hline & $\{$ 乾燥\} & 乾燥した & 2 & 0 & 0 & 0 & 2 \\
\hline \multirow{2}{*}{ 【心象】 } & $\{$ 印象 & ピュアな, 落ち着いた & 75 & 90 & 58 & 56 & 279 \\
\hline & \{価值\} & 価値のある, 豪華な & 25 & 30 & 22 & 27 & 104 \\
\hline \multirow{4}{*}{ 【空間】 } & $\{$ 印象\} & 明るい空間，広い空間 & 31 & 56 & 12 & 6 & 105 \\
\hline & $\{$ 価值 $\}$ & 質の高い空間 & 32 & 33 & 9 & 3 & 77 \\
\hline & $\{$ 欲求 $\}$ & 快適な空間 & 16 & 15 & 23 & 25 & 79 \\
\hline & & 計 & 394 & 446 & 255 & 261 & 1356 \\
\hline
\end{tabular}

合から木材の特徵を評価している。また， $\{$ 強度 $\},\{$ 応用 $\},\{$ 実用 $\}$, \{品質\}などの指摘回数が多いことから，木材のもつ材料的な特徽を 捉え，木材の品質，空間で使用寸る際の実用性や応用性の高さを評 価している。さらに，【空間】の\{価值 $\}$ や印象 $\}$ の指摘回数が非 専門家に比べて多いことから，空間の印象だけでなく，空間の獲得 しうる価值を考慮して木材を評価していることが読みとれる。

非専門家における評価の傾向として，木材の $\{$ 色相 $\},\{$ 明度 $\}$, 【色】 の \{印象\} など色に関する項目の指摘回数が全般的に多いことから， 木材のもつ色に関する特徵やそれから受ける印象によって，住空間 に用いる木材を評価している。さらに，専門家に比べて【空間】の \{欲求\} の指摘回数が多いことから，木材を空間に用いた際の印象や 価值よりも，木質空間における快適さなどの空間に対する欲求によっ て，木材を評価する傾向が強いことが読みとれる。 


\section{2 各属性における評価の傾向}

続いて, 各評価項目の指摘回数を用いた「被験者の各属性 $\times$ 小分類」 によるコレスポンデンス分析を行い，被験者における各属性と評価 項目の関連の強さをグラフ上の距離に転換して模式化した(図 1 ) 注7)。

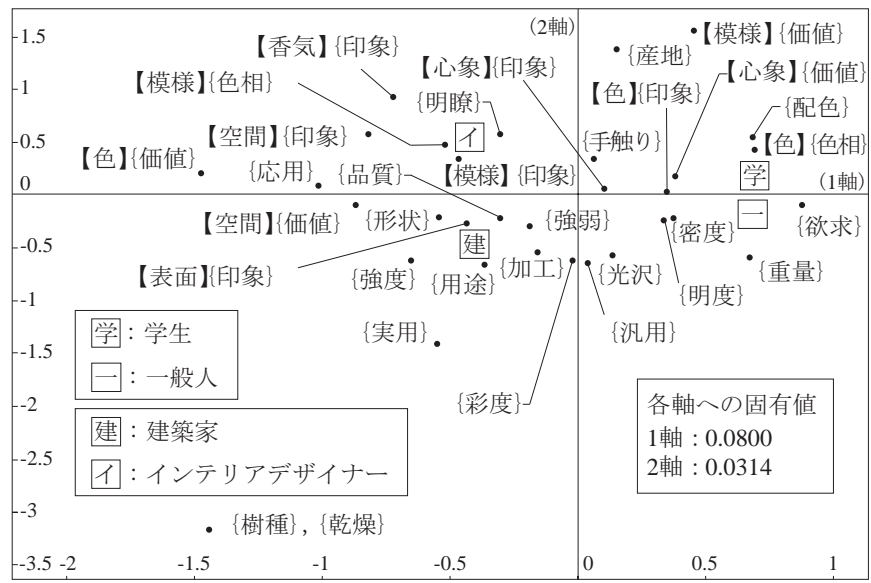

図 1 各属性におけるコレスポンデンス分析による木材の評価傾向

学生では, \{色相\}, 配色\} の指摘回数が多く距離も近いことから, 色に関する特徴を重視して木材を評価しているといえる。一般人では, \{重量\}, \{欲求\} の指摘回数が多く距離も近いことから, 重さや木材を 用いた空間の機能性や快適性などの欲求を重視して木材を評価してい るといえる。また, 学生と一般人の距離は近く, 色, 木目, 重さ, 表 面状態に関する項目が多くみられた。よって, 非専門家は木材の視覚 的及び物理的な特徴から木材を評価する傾向が強いことが読みとれる。 建築家では, \{加工\}, \{用途\}, \{強度\}, \{品質\}, 【表面】の $\left\{\mathrm{F}^{-6 h c^{\prime}}\right\}$, \{形状\} などの指摘回数が多く距離も近いことから, 加工状態, 汎用性, 強度, 品質に加えて, 木目の形状や表面から受ける印象など, より多 角的な側面から木材を評価しているといえる。インテリアデザイナー では,【模様】の $\{$ 色相 $\},\{$ 明瞭 $\}$, 【模様】の $\{$ 印象 $\}$, 【空間】の $\{$ 印象 $\}$ の指摘回数が多く距離も近いことから，木目の色や明暗，木目から受 ける印象に加えて，木材を用いた空間が与える印象を重視して木材を 評価しているといえる。さらに, 建築家の近くには加工度合い, 強度, 実用性などの項目が布置され，インテリアデザイナーの近くには色， 木目の印象や価值，木材を用いた空間の印象に関する項目が布置さ れた。よって, 建築家は木材の物性的な特徴, インテリアデザイナー は木材を空間に用いた際の印象や価值など，空間設計とより密接に 関わる項目から木材を評価する傾向が強いことが読みとれる。

\section{4. 評価項目を用いた被験者の評価構造の類型化}

\section{1 カテゴリースコアによる軸の解釈}

5 名以上が指摘した評価項目注8) を用いた「被験者 $\times$ 評価項目」の 0/1 型データによる数量化III類分析を行う。さらに，カテゴリースコ アが絶対值 1.5 以上の項目注9) をもとに軸の解釈を行う注10)（表 4 ）。

第 1 軸における正の值の「バランスのとれた木目」,「黄系の色」,「快 適な空間」, 負の值の「有機的な空間」,「芸術的な」,「現代的な空間」 などの項目から，第 1 軸は馴染みのある木目や色，日々の空間の快 適さや木材を用いた空間が獲得しうる特有性を示していると解釈で きる。よって，第１軸は「日常性↔特有性」の軸と位置づけられる。
次に，第 2 軸における正の值の「灰系の色」，「赤系の色」，「黄系の 色が少ない, 負の值の「重い」,「強度のある」,「無加工の」などの 項目から，第 2 軸は木材のもつ色に関わる視覚的な要素や木材の物 質的な性質を示していると解釈できる。よって，第２軸は「視覚性 $\Leftrightarrow$ 物質性」の軸と位置づけられる。続いて，第３軸における正の值 の「快適な」,「柔らかい」,「調和のとれた」, 負の值の「現代的な空間」, 「安定した空間」、「暖かい」などの項目から，第３軸は木材を用いた 空間のイメージや木材を用いた空間の機能性を示していると解釈で きる。よって, 第 3 軸は「心象性↔機能性」の軸と位置づけられる。

表 4 数量化正類分析による各評価項目のカテゴリースコア

\begin{tabular}{|c|c|c|c|c|c|}
\hline 評価項目 & 第1軸 & 評価項目 & 第2軸 & 評価項目 & 第3蟿 \\
\hline ランスのとれた木目 & 2.4123 & 灰系の色 & 3.4542 & 快適な & \\
\hline 安全な空間 & 2.2566 & 赤系の色 & 2.0131 & 柔らかい & \\
\hline の色 & 2.0314 & 黄系の色が少ない & 1.7167 & 調和のとれた & 888 \\
\hline な空間 & 1.9788 & 広い空間 & 1.5260 & 密度の低い & 1.653 \\
\hline ランスのとれた色 & 1.9641 & 快適な空間 & 1.4408 & 落ち着いた木目 & \\
\hline 馴染みのある色 & 1.8024 & ジランスのとれた色 & 1.3932 & 加工度合 & 400 \\
\hline 安定した空間 & 1.7964 & 調和のとれた & 1.2188 & 明るい & 40 \\
\hline ఎれた & 1.7373 & 新鮮な & 1.0290 & 快適な空間 & \\
\hline 調和のとれた & 1.5482 & 広い木目 & 0.9680 & 地元由来の & \\
\hline 価值のある & 1.3682 & 現代的な空間 & 0.9444 & 広い空間 & 1.25 \\
\hline 重い & \begin{tabular}{|l||}
1.2957 \\
\end{tabular} & バランスのとれた木目 & 0.9015 & 自然な空間 & \\
\hline の色 & 1.2639 & 興味深い木目 & 0.8140 & 広い木目 & \\
\hline 加 & 1.2109 & 明るい空間 & 0.7244 & 滑らかな & 1 \\
\hline コントラストのある & 1.1875 & 黄系の色 & 0.7199 & 強度のある & \\
\hline 安心する空間 & 0.9108 & 明るい色 & \begin{tabular}{|l|}
0.7164 \\
\end{tabular} & 無加工の & \\
\hline 規則的な木目 & 0.8969 & 落ち着いた空間 & 0.6918 & 重い & \\
\hline 暗い色 & \begin{tabular}{|l|}
0.7647 \\
\end{tabular} & 中間色の & 0.6796 & 磿かれた & \\
\hline 次色 & 0.7161 & 中間的な & 0.6702 & 規則的な木目 & \\
\hline の低い & 0.7126 & 直線的な木目 & 0.5813 & ピュアな & \\
\hline うある & 0.6979 & シンプルな空間 & 0.4813 & 黄系の色 & \\
\hline 滑らかな & 0.6291 & リラックスした空間 & 0.4085 & 実用的な & \\
\hline ックスした空間 & 0.5541 & 磨かれた & 0.3976 & 暖かい空間 & \\
\hline いた空間 & 0.5088 & 興味深い & 0.3674 & 落ち着いた空間 & \\
\hline 現代的な & $0.4544 \mid$ & 汎用性のある & 0.3196 & 有機的な空間 & \\
\hline 空間 & 0.4353 & 弍的な & 0.2786 & い色 & \\
\hline 有 $\omega$ & 0.4110 & 暖かい & 0.2688 & 直線的な末目 & \\
\hline 灰系の色 & 0.3988 & 背景的な & 0.2250 & 自然な色 & \\
\hline 適な & \begin{tabular}{|l||}
0.2521 \\
\end{tabular} & 伝統的な & 0.2238 & 特有の空間 & \\
\hline 広い木目 & \begin{tabular}{|l||}
0.0819 \\
\end{tabular} & 茶系の色 & 0.2001 & 多彩な & \\
\hline 由来の & \begin{tabular}{|l||}
0.0370 \\
\end{tabular} & い経年変化をする & 0.1805 & 色 & \\
\hline 高い & -0.0366 & 規則的な木目 & 0.1024 & 質の高い & 187 \\
\hline 今色 & -0.0414 & 新鮮な色 & 0.0893 & 的な & \\
\hline 《のある & -0.0578 & 暖かい色 & 0.0151 & 空間 & \\
\hline 伝統的な & -0.0684 & 明るい & 0.0305 & 本物の & \\
\hline の色 & -0.1213 & 落ち着いた木目 & \begin{tabular}{|l|}
0.0151 \\
\end{tabular} & 白系の色 & \\
\hline 黄系の色が少ない & -0.1241 & 多彩な組合せ & -0.0448 & 自然な & \\
\hline W色 & -0.1622 & 本物 & -0.0488 & 新鮮な色 & \\
\hline 3い & -0.1888 & 馴染みのある & -0.0488 & 興味深い & \\
\hline の色 & -0.1895 & ロントラストのある色 & -0.0489 & 多彩な組合せ & \\
\hline 暖かい空間 & -0.2490 & 地元由来の & -0.0659 & 汎用性のある & \\
\hline 木らしい & -0.2963 & 多彩な & -0.0691 & リラックスした空 & \\
\hline 色の & -0.3 & 自然な色 & -0.1 & 環境に優しい & \\
\hline 空間 & -0.3655 & 加工度合 & -0.1436 & 馿染みのある & \\
\hline 新鮮な & 11 & 滑らかな & -0.2 & 茶系の色 & \\
\hline ち着いた木目 & -0.4786 & 自然な空間 & -0.2532 & 芸術的な & \\
\hline 興味深い木目 & -0.5 & 特有 & -0.2759 & 興味深い木目 & \\
\hline 自然な & -0.6365 & 馴染みのある色 & -0.2788 & 茶系の色が少な & \\
\hline ユアな & $|-0.6571|$ & 価値のある空間 & -0.3175 & コントラストのある代 & 148 \\
\hline 興味深い & -0.6 & 白系の色 & -0.3404 & 木らしい & \\
\hline トのある色 & -0.6 & 柔らかい & -0.3491 & 特有の & \\
\hline एब & & 自然な & -0.3617 & 安心する空間 & \\
\hline 直線的な木目 & -0.7 & 暖かい空間 & -0. & ルな空間 & \\
\hline 長く使用できる & & 荎術的な & -0. & 良い経年変化をす & \\
\hline 柔らかい & -0. & 有機的な空間 & & 灰系の色 & \\
\hline ब) & -0.8953 & 特有の空間 & -0.4957 & 中間色の & \\
\hline 度合 & & 密度の低い & -0.6030 & バランスのとれた木目 & \\
\hline 小色 & -0.9 & 質の高い & -0.6 r & 伝統的な & \\
\hline 的な & -1.06 & 快適な & -0.7 & 暖かい色 & \\
\hline 自然な空間 & & 実用的な & -0.7882 & 馴染みのある色 & \\
\hline 汎用性のある & -1.1764 & 暗い色 & -0.9308 & バランン & \\
\hline 特有の空間 & -1.1812 & 環境に優しい & -1.0006 & 現代的な & \\
\hline シンプルな空間 & -1.2322 & 木らしい & & 万空間 & \\
\hline 多彩な組合せ & -1.2874 & 安定した空間 & -1.3804 & 価値のある & \\
\hline 率な & & ピュアな & -1.4607 & 薪鮮な & \\
\hline しい & $|-1.5591|$ & 無加工の & -1.6571 & ストのある & \\
\hline 多利 & -1.5970 & 安全 & -1.9078 & W & \\
\hline 価値の & -1.6111 & 長く使用できる & & 安定 & \\
\hline い経年変化をする & -1.6246 & 強度のある & -2.3448 & 中間的な & -1.0 \\
\hline 中間的な & $\mid-1.6937$ & コントラストのある & -2.4970 & 安全な空間 & \\
\hline 現代的な空間 & -1.7121 & 重 & -2.5389 & 長く使用できる & \\
\hline 芸術的な & $\mid-1.8061$ & 安心する空間 & -3.0839 & 現代的な空間 & \\
\hline 有機的な空間 & -2.0817 & ある & -3.8322 & 赤系の色 & \\
\hline & 0.2671 & & 0.2282 & & \\
\hline 相関係数 & 0.5168 & 相関係数 & 0.4777 & 相関係数 & \\
\hline 累積寄与率 & $8.59 \%$ & 累積寄与率 & $15.93 \%$ & 累積寄与率 & 22 \\
\hline
\end{tabular}

※表中の網掛けは，カテゴリースコアが絶対值1.5以上の評価項目を示寸。 


\section{2 クラスターの類型化と特徵}

次に，前節における内装用木材の評価項目における数量化亚類分 析から得られた被験者のサンプルスコアをもとに，前稿8) と同様に ward 法，ユーグリッド距離を採用してクラスター分析を行った。ク ラスター分析から得られたデンドログラムを以下に示す（図 2 )。

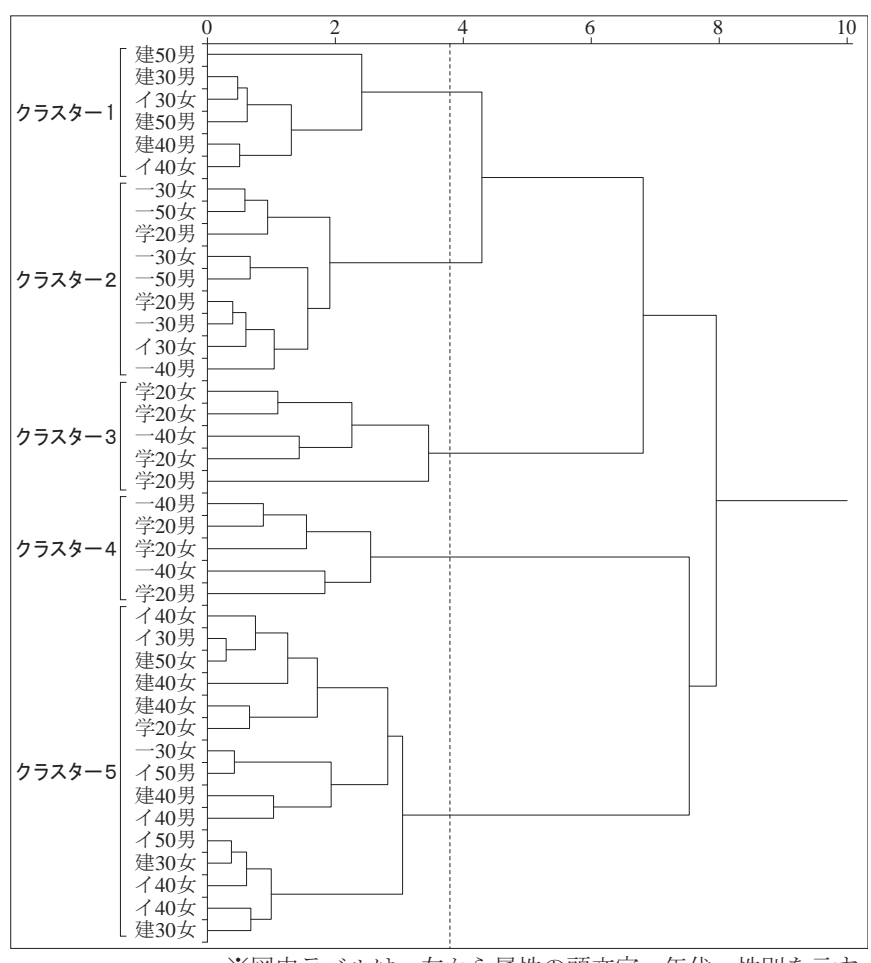

図 2 クラスター分析によるデンドログラム

続いて，デンドログラムを等しい類似度で区切ることにより，ク ラスターの類型化を行い，5つのクラスターを得た。各クラスターに おける住空間に用いる内装用木材に対する評価の傾向を把握するた め, 第 1 軸と第 2 軸, 第 1 軸と第 3 軸によるサンプルスコアの二次 元散布図をそれぞれ作成した（図 3，4）。

クラスター分析の結果, クラスター 1,5 のようにクラスターを構 成する被験者が主に専門家であるものと，クラスター 2 〜のよう に構成する被験者が非専門家であるものが明確に分かれた。これは, 専門家と非専門家それぞれの評価の傾向が個別のクラスターに表れ ていることを示唆しているといえる。

クラスター 1 には, 建築家 4 名, インテリアデザイナー 2 名の計 6 名の被験者が属し, 被験者は全て専門家のみによって構成されて いる。散布図におけるクラスター 1 の位置をみると,「特有性」と「心 象性」の軸寄りに布置していることから，クラスター 1 は木材を用 いた空間の特有性に加え，空間を設計する際に周囲と調和したイメー ジを与える木材を求めるクラスターであると考えられる。

クラスター 2 には，インテリアデザイナー 1 名, 学生 2 名, 一般 人 6 名の計 9 名の被験者が属し，年齢の隔たりはみられないが，計 9 名の被験者のうち 6 名を一般人が占めている。散布図におけるクラ スター 2 の位置をみると, 「日常性」と「心象性」の軸寄りに布置し ていることから, クラスター 2 は日常の生活や馴染みのある空間と して周囲と調和する木材を求めるクラスターであると考えられる。

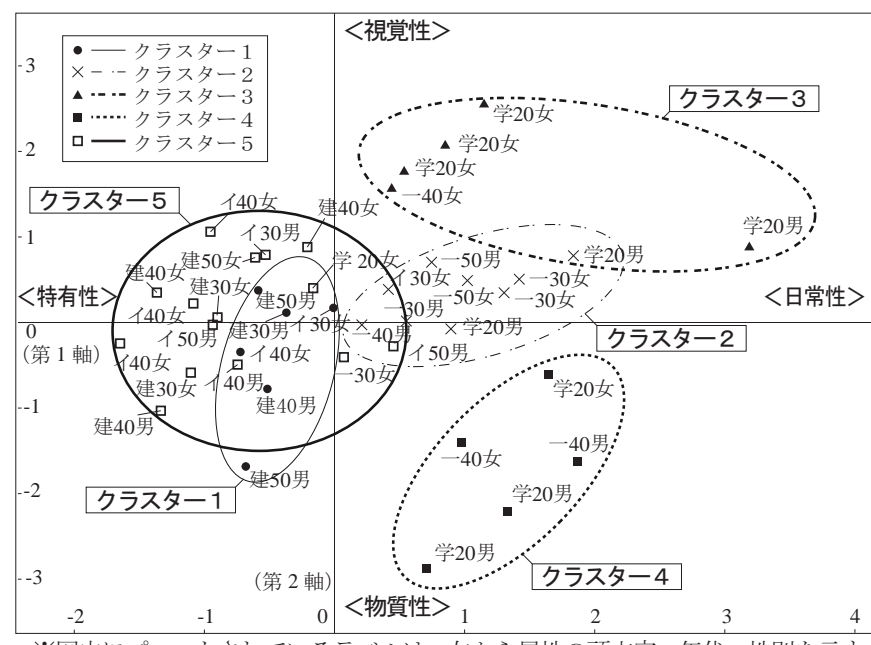

※図中にプロットされているラベルは，左から属性の頭文字，年代，性別を示寸。 図 3 数量化正類分析による第 1 軸一第 2 軸のサンプルスコア散布図

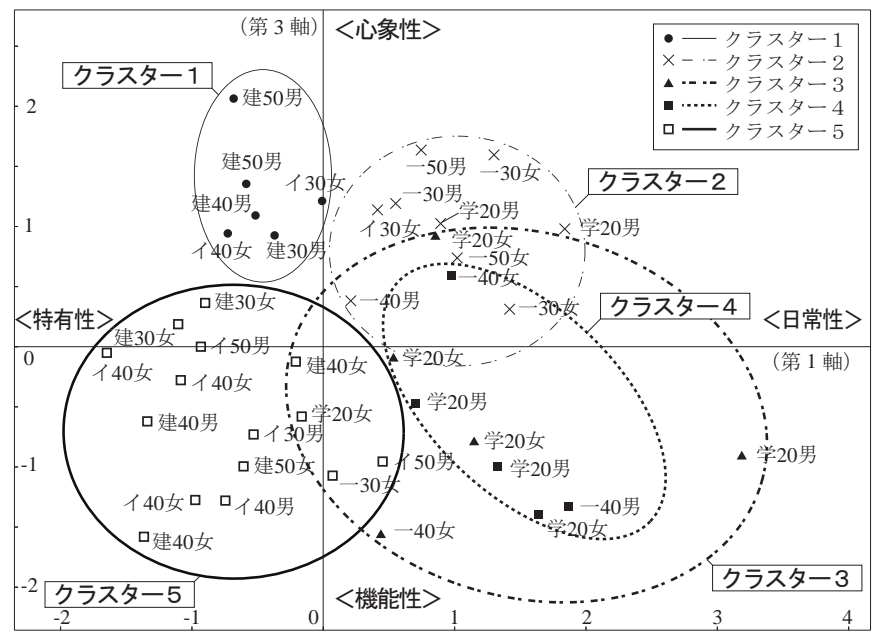

※図中にプロットされているラベルは，左から属性の頭文字，年代，性別を示す。

図 4 数量化正類分析による第 1 軸-第 3 軸のサンプルスコア散布図

クラスター 3 には, 学生 4 名, 一般人 1 名の計 5 名の被験者が属し, 特に学生の被験者が多く，また計 5 名の被験者のうち 4 名を女性が 占めている。散布図におけるクラスター 3 の位置をみると, 「日常性」 と「視覚性」の軸寄りに布置していることから, クラスター 3 は馴 染みのある木材を用いることによる日常性に加えて，木材を視覚的 な観点から評価する被験者が属するクラスターであると考えられる。

クラスター 4 には, 学生 3 名, 一般人 2 名の計 5 名の被験者が属し, クラスター 3 と同様に，非専門家である学生，一般人の夕によって 構成されるクラスターである。散布図におけるクラスター 4 の位置 をみると,「日常性」と「物質性」の軸寄りに布置していることから, クラスター 4 は, 木材に対する親しみや馴染みが感じられる木材を 用いることによる空間の日常性に加えて, 木材の物質的な要素に着 目しているクラスターであると考えられる。

クラスター 5 には, 建築家 6 名, インテリデザイナー 7 名, 学生 1 名, 一般人 1 名の被験者が属し, 被験者の多くを建築家とインテリ アデザイナーが占めている。散布図におけるクラスター 5 の位置を みると,「特有性」と「機能性」の軸寄りに布置されていることから, クラスター 5 は木材のもつ特有性に加えて, 木材の機能性によって 価值を見出すクラスターであると考えられる。 


\section{5．住空間に用いる内装用木材に対する評価構造}

複雑にネットワーク化された評価構造を分析するため，各クラス ターが強い傾向を示した軸におけるカテゴリースコアが絶対值 1.5 以 上である評価項目を基準とし，階層的な繋がりを図示した評価構造 図を作成した（図 5，6）。その際，各クラスターの特徵をより明確 に把握するため, 基準とした評価項目と関連する項目については, クラスター内の複数の被験者が指摘した項目に絞って分析を行った。

\section{1 クラスター別の評価の傾向}

クラスター 1 は，属する被験者は全て専門家であることから，専 門家の評価傾向が明確に表れているクラスターだと考えられる。上 位項目に「有機的な空間」，「落ち着いた空間」，「多彩な」などがみ られ，下位項目に「落ち着いた木目」，「密度の低い」,「直線的な木目」 などがみられる。これより，直線的でシンプルな木目や，木材の軽 さから空間を設計する際の多彩さを捉え，特有の空間を実現しよう としていると考えられる。また，下位項目の「広い木目」は，「落ち 着いた木目」に加えて，「興味深い木目」一繋がり，「興味深い木目」 は「有機的な空間」一繋がることから，空間の意匠的な要素として， 木目の特徴にも着目していると考えられる。さらに，「背景的な」が 「落ち着いた空間」に繋がることから，木材を周囲の環境に馴染ませ ながら空間を設計することに価値を見出していることが読みとれる。

クラスター 2 は，属する被験者の多くは非専門家であり，9名中 6 名が一般人であることから，一般人の評価傾向が表れているクラス ターだと考えられる。上位項目に「快適な空間」,「快適な」,「リラッ クスした空間」などがみられ，下位項目に「調和のとれた」，「規則的 な木目」,「バランスのとれた色」などがみられる。これより，木材の

もつ色のバランスや規則的で調和がとれた木目の木材を用いること で，居心地のよい空間を求めていると考えられる。また，「自然な色。 から「明るい色」，「明るい空間」，「快適な」へ繋がることから，木 材による自然さや明るさが空間と調和寸ることによる快適さを求め ていると考えられる。さらに,「自然な色」,「茶系の色」や「黄系の色」 などが，中位項目の「目に優しい」に繋がることから，黄色や茶色 など色味のある木材から自然さを捉え，さらには視覚的な安心感か ら木質空間の快適さを求めていることが読みとれる。

クラスター 3 は，属する被験者は全て非専門家であり， 5 名中 4 名 が学生であることから, 学生の評価傾向が明確に表れているクラス ターだと考えられる。上位項目に「快適な空間」「「広い空間」,「新鮮な」 などがみられ，下位項目に「赤系の色」，「灰系の色」，「黄系の色が 少ない」などがみられる。これより，木材の色彩的な要素に着目す ることで，木質空間の印象を捉えていると考えられる。また，「赤系 の色」や「灰系の色」などから，「快適な空間」に繋がる途中で，中 位項目の「現代的な」へ繋がることから，フィンランドにおいて馴 染みのある黄系の色ではなく, 赤系の色や灰系の色のようなフィン ランド人にとって馴染みのない色を新鮮な要素と捉え，木材の現代 的な側面を評価していることが読みとれる。

クラスター 4 は，属する被験者が全て非専門家であることから， 非専門家の評価傾向が明確に表れているクラスターだと考えられる。 クラスター 4 では，上位項目に「長く使用できる」，「価值のある」， 「安全な空間」などがみられ，下位項目に「重い」，「自然な表面」「「コ ントラストのある」などがみられる。これより，木材の重さや密度 などの物質的な性質から，長く使用できる安心感のある空間を求め

下位項目|被験者

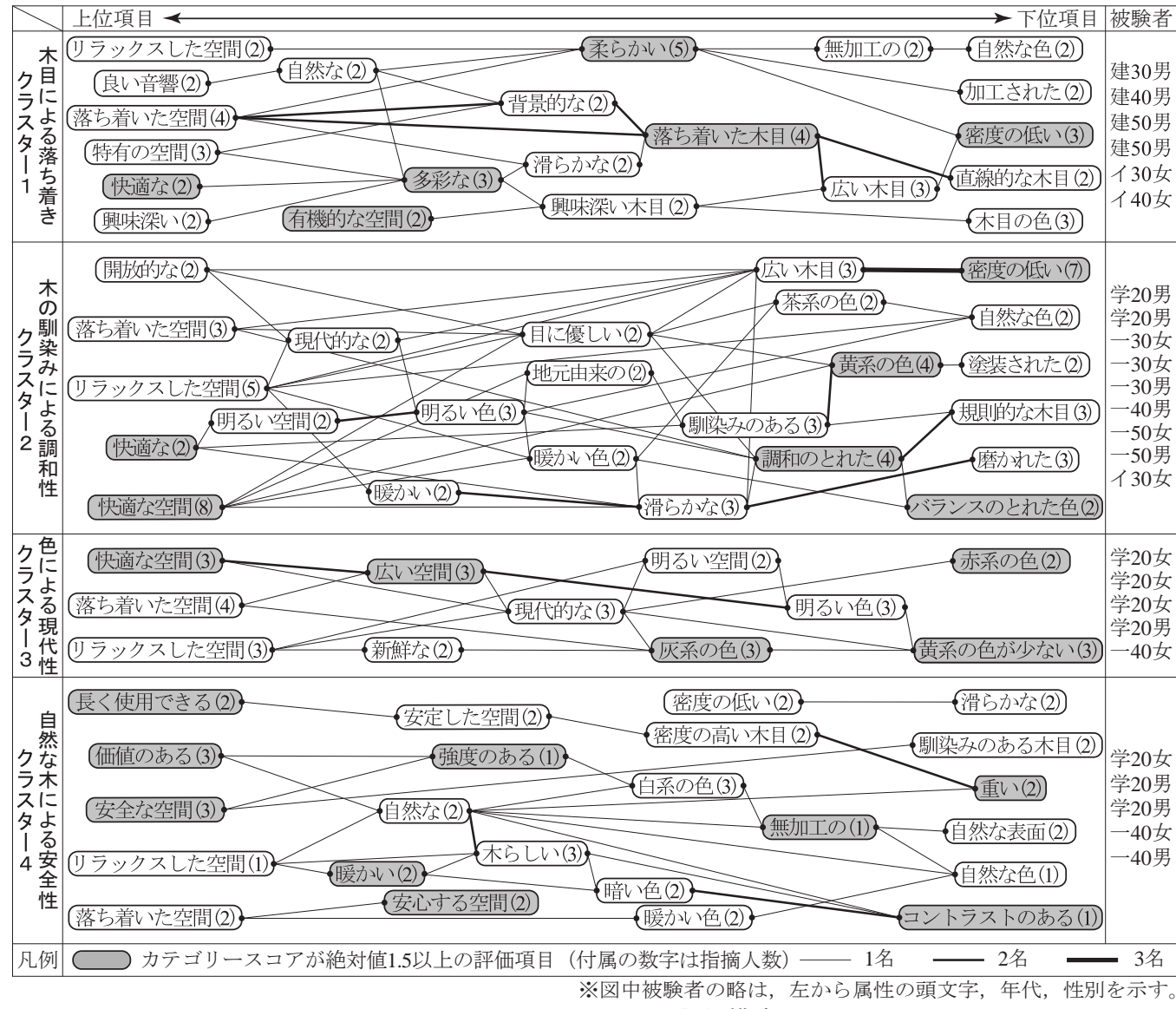

図 5
※図中被験者の略は, 左から属性の頭文字, 年代, 性別を示寸。 ※図中被験者の略は,
ていると考えられる。また，中 位項目の「強度のある」は,「自 然な色」,「無加工の」,「白系の 色」と繋がることから，加工が されていない自然な木材によっ て空間の安全性を評価している と考えられる。さらに，上位項 目の「価値のある」は「強度の ある」の他に「自然な」からも 繋がることから，自然で強度の ある木材に価值を見出している ことが読みとれる。

クラスター 5 は，属する被 験者の 15 名中 6 名が建築家, 7 名がインテリアデザイナーで あることから，専門家に属す る建築家とインテリアデザイ ナー双方の評価傾向が表れて いるクラスターだと考えられ る。クラスター 5 では，上位 項目に「価値のある空間」,「良 い経年変化をする」，「特有の空 間」などがみられ，下位項目に 「芸術的な」,「白系の色」,「汎 用性のある」などがみられる。 


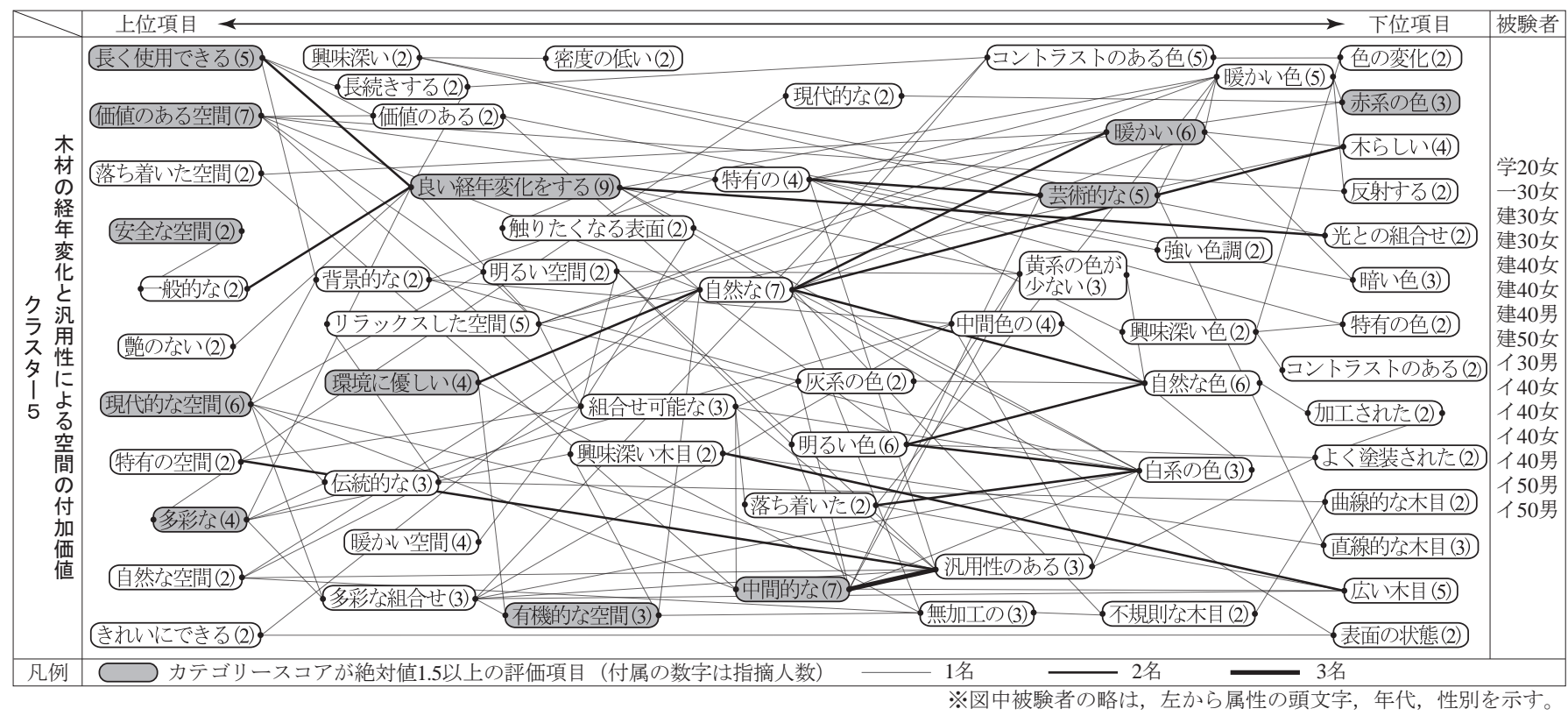

図 6 クラスター5の評価構造図

これより, 木材を空間設計に用いる際の使い方の多様さから, 特徴 的な空間を評価していることが読みとれる。また，クラスター 5 に は多様な評価項目が存在する中，「自然な」や「組合せ可能な」，「汎 用性のある」が多くの評価項目と繋がっている。さらに, 下位項目 の「自然な色」から「自然な」が中位項目の「環境に優しい」へ繋 がる一方で,「興味深い木目」から「有機的な空間」も「環境に優しい」 に繋がることから, 専門家として空間の意匠性に加えて, 環境的な 影響にも配慮しながら設計に取り組んでいる点が読みとれる。特に, 上位項目の「価值のある空間」は「芸術的な」や「特有の」から繋 がることから，木材のもつ固有性によって空間に価值を付加してい ると考えられる。また, 「価值のある空間」は「汎用性のある」や「組 合せ可能な」からも繋がることから，木質空間の付加価值を創出す る要素として, 木材のもつ固有性と木材同士の組合せや空間設計一 の応用が多様な機能性の 2 つ特徴を捉えることができる。

\section{2 クラスター間の比較考察}

前節の各クラスターにおける評価の傾向に加えて, クラスター間 で共通して用いられる項目, 各クラスターで特徴的な項目, 各項目 同士の繋がりから，クラスター毎の評価の傾向と専門家と非専門家 の内装用木材に対する評価における相違点や共通点を考察する。

クラスター 1,5 において,「背景的な」が共通して用いられてい る。この項目は, クラスター1では「落ち着いた木目」から慗がる ことから, クラスター 1 の被験者は落ち着いた印象を与える木目に よって木材の背景的な印象を評価していると考えられる。クラスター 5 では, 「中間色の」, 「黄系の色が少ない」,「灰系の色」と繋がるこ とから, クラスター 5 の被験者は黄味が少なく, 灰系の中間的な色 によって空間の背景として馴染む木材を評価していると考えられる。 また,クラスター 5 の「背景的な」は「特有の」からも繋がることから, 木材が背景として特有な印象を与える点も評価しており, クラスター 5 の「背景的な」には, 空間へ馴染む木材と特徵をもった背景を実 現する木材としての 2 つ捉え方があることが読みとれる。

クラスター 2,3 において, 「現代的な」が共通して用いられてい る。この項目は, クラスター2では「広い木目」から繋がることから，
クラスター 2 の被験者は木目が少なく, 軽量な木材の性質を現代的 な要素として評価していると考えられる。また，クラスター 3 では 「現代的な」が「赤系の色」や「灰系の色」から繋がることより, 黄 系や白系の色の木材がフィンランド人にとって見慣れた色であるこ とから, クラスター 3 の被験者は普段馴染みのない色によって木材 の現代性を評価していることが読みとれる。

クラスター 4, 5 において「価值のある」が共通して用いられ，こ の項目はクラスター 4,5 の両方で「自然な」から繋がることから, 両クラスターの被験者が自然素材の木材を用いた空間に価值を見出 していると考えられる。一方で「価值のある」は，クラスター4で は「強度のある」からも繋がり, クラスター 4 の被験者は木材の強 度による価值を評価していると考えられる。また, クラスター 5 では, 「価值のある」は「現代的な」からも繋がることより, クラスター 5 の被験者は木材を用いた空間が獲得する意匠性から空間の価値を評 価していることが読みとれる。

クラスター $1,4,5$ において, 「自然な」が共通して用いられてい る。この項目は, クラスター1では「柔らかいかから繋がり, クラスター 4 では「白系の色」から繋がる。クラスター 1 と 4 を比較すると, ど ちらの評価項目も「無加工の」から繋がることから, クラスター1の 被験者は無垢の木材の柔らかさを木材の自然さとして評価している と考えられる。その一方で, クラスター 4 の被験者は明度の高い木材 の色相から，木材の自然さを評価していると考えられる。さらに，ク ラスター5では「自然な」は「暖かい」から繋がることから, クラスター 5 の被験者は木材自体の暖かさを捉えることで, 木材の自然さを評価 していると考えられる。このように木材の䁔かさから, 木材の自然さ を捉えている点は, 冬が長く寒さの厳しいフィンランドの被験者の木 材に対する特有の評価が表れていると考えられる。さらに, 専門家で ある建築家とインテリアデザイナーが多く属するクラスター 5 と, 学 生と一般人の非専門家のみで構成されるクラスター 4 において, 木材 の自然さを, 「白系の色」のように木材の視覚情報から評価する点と, 「柔らかい」,「暖かい」のように木材から受ける心象や印象によって 評価する点に非専門家と専門家の評価の違いが読みとれる。 


\section{3 専門家の評価構造の比較考察}

専門家における評価の共通点や相違点をより詳細に分析するため, 最も多い計 15 名の被験者が属しており，専門家のみで 13 名の被験 者を占めているクラスター 5 の評価構造図を, 建築家とインテリア デザイナーに分解した図を作成し比較考察を行う（図 7 )。

まず，建築家とインテリアデザイナーそれぞれの評価構造を比較 すると, 「赤系の色」,「表面の状態」などの木材の色や表面状態に言 及した建築家による独自の評価項目に対して, インテリアデザイナー では「暗い色」,「特有の色」,「木らしい」,「色の変化」,「直線的な木目」, 「光との組合せ」のように，木材の色や木目，木材の性状や意匠性に 関わる多種多様な独自の項目がみられた。

建築家の評価構造では「汎用性のある」，「特有の空間」が独自の 項目として用いられている。これより，建築家は木材の多様な利用 のされ方や木材を用いることで空間が獲得する特有性を考慮するこ とによって，木質空間の可能性を評価していることが読みとれる。

インテリアデザイナーの評価構造では「特有の色」が独自の項目 として用いられている。この「特有な色」は，「特有の」に繋がり， 最終的に「価值のある空間」へ繋がっている。これより，インテリ アデザイナーは木材のもつ特徵的な色によって，価值のある空間の 実現を試みていることが読みとれる。さらに，「特有の」は，「強い 色調」からも繋がることから,インテリアデザイナーは空間をイメー ジする際に, 馴染みのない色相やアクセントとなるような色味をもっ た木材に対して価值を見出していることが読みとれる。また，イン テリアデザイナーの評価構造における「価值のある空間」は，建築 家と比較して指摘回数が多く, 多様な下位項目から繋がる「自然な」 の指摘回数が多い点も，評価の特徴として捉えることができる。さ らに,「自然な」には「暖かい」も慗がることから，インテリアデザ イナーは色から木材のもつ暖かさを認識することによって，木材の 自然さを評価していることが読みとれる。
次に，建築家とインテリアデザイナーそれぞれの評価構造におい て共通して用いられる評価項目として，下位項目の「自然な色」が 挙げられる。「自然な色」は，建築家とインテリアデザイナーの双方 において「白系の色」に繋がっている。さらに,インテリアデザイナー では「灰系の色」に繋がり，最終的に「中間的な」一繋がっている。 これより，建築家は空間を設計する際に，木材を他の材料とも多彩 に組み合わせることを想定し，汎用性のある白系の色の木材を評価 していることが読みとれる。その一方で，インテリアデザイナーは， 明度の低い灰系の色を中間的な印象を与える木材として評価してい ることが読みとれる。これらの点に，「自然な色」に対する建築家と インテリアデザイナーの捉え方の違いが読みとれる。

さらに，建築家とインテリアデザイナーの両者において，多くの 上位の評価項目に繋がる項目として，「良い経年変化をする」がみら れる。この「良い経年変化をする」は，建築家とインテリアデザイ ナーの両者において, 最終的に「長く使用できる」へ繋がっている。 これより，建築家とインテリアデザイナーは，空間に木材を用いる 際の耐久性の観点から，木材の時間経過に対寸る性能や変化にも着 目し，木材や木材を用いた空間を評価していることが読みとれる。 また，「良い経年変化をする」に繋がる下位項目として，建築家では 「表面の状態」が繋がり,インテリアデザイナーでは「光との組合せ」 が繋がっている。これらより，建築家とインテリアデザイナーの両 者とも，木材の表面状態から，時間の経過による価值創出を捉えて いるが，建築家は木材表面の材料的な品質をより重視していること が読みとれる。一方で，インテリアデザイナーは，木材と光の組合 せによる視覚的な効果にも着目していることが読みとれる。さらに, インテリアデザイナーにおける「良い経年変化をする」は，インテ リアデザイナー独自の「一般的な」,「安全な空間」へ繋がることから， 木材の視覚的な変化を考慮しながらも，木材の性能や木材を用いた 空間の安全性の確保を試みていることが読みとれる。

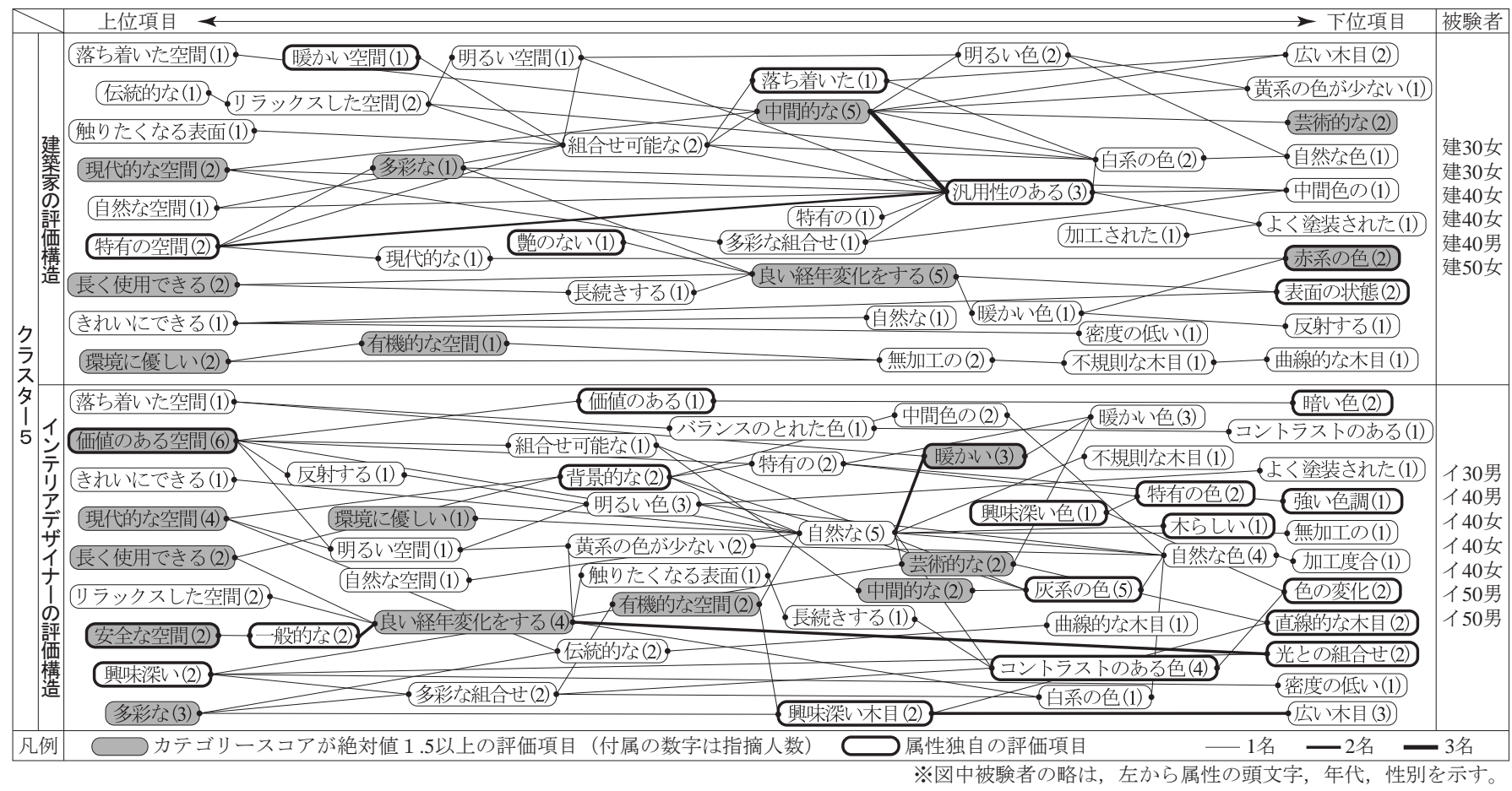

図 7 クラスター5における建築家とインテリアデザイナーの評価構造図 


\section{6. 結論}

フィンランドの学生は色に関する特徵, 日々の生活に関わる空間 の落ち着きや快適性などによって, 木材を評価していることが明ら かとなった。また，赤系や灰系の色などフィンランド人にとって馴 染みのない色から, 木材の新鮮さや現代性を捉えていた。一方, フィ ンランドの一般人は，木材に対する馴染みや木材を使用した際の周 囲との調和, 木材の視覚的な特徴に基づく安心感から, 木質空間の 快適性を求めていることが明らかとなった。

フィンランドの建築家は, 空間に木材を利用する際の多様性によっ て, 空間に用いる木材を評価していることが明らかとなった。また, それらの木材を用いることで実現される空間の特有性から，木質空 間に対する可能性を捉えていた。一方，フィンランドのインテリア デザイナーは，特徵的な色や一般的に見慣れない木目などの視覚的 に際立った木材に加えて，木材を用いることで空間が獲得する意匠 性を重視した設計を試みていることが明らかとなった。また，建築 家とインテリアデザイナー両者の評価における共通点として，木材 の経年変化を意識した設計を試みており，木材を空間に用いること による環境負荷への配慮もみられた。

以上から，フィンランドの専門家と非専門家の評価構造では, 評 価傾向が属性によって明確に分かれたことから，各属性が独自の評 価基準をもっていることが明らかとなった。さらに，フィンランド 人が，木材の特徵から木材に対する現代性や暖かさを捉えている点， 木材利用によって環境負荷の低減一配慮している点に，これまで長 く厳しい冬に耐えながら生活を営み，自国産の木材を継続的に活用 してきたフィンランド人の評価の特徴が表れていた。

今後の展望として, 前稿 81 で得られた日本の専門家と非専門家を 対象とした分析結果と, 本稿で得られた分析結果を比較考察するこ とで，木質空間設計や国産材の有効活用に関わるより具体的な手法 や方策の検討を行いたい。また，将来的には日本とフィンランド以 外の国の被験者を対象とした実験を行い，さらに，擬似木材や混合 木材などのエレメントの種類も増やして実験を行っていくことで, より体系的な研究に取り組んでいきたいと考えている。

\section{謝辞}

本稿を進めるにあたり，フィンランドの専門家，非専門家の方々 には，限られた時間の中で個別インタビューに参加頂き，本稿にお いて多大な御協力を頂きました。また, 田原聖氏（名古屋工業大学 大学院工学研究科博士前期課程）には，本論文を進めるにあたって 資料，論文作成において多大な御協力を頂きました。文末ではあり ますがここに記して感謝申し上げます。

注

注 1）一般人は，3 年以上の勤務経験がある社会人を対象とした。また，学 生及び一般人は，建築，インテリア，木材に関連する分野を専攻又は 専門としていない者を対象とした。

注 2）木材の大きさは，W $100 \mathrm{~mm} \times \mathrm{H} 250 \mathrm{~mm} \times \mathrm{D} 10 \mathrm{~mm}$ とし，全ての被験者が 容易に手にとり, 視覚, 触覚, 嗅覚など様々な観点から, 木材のもつ 特徴を十分観察することができるように配慮した。また，各木材は無 節で, 模様, 色, コントラストなどに極端な差が出ない様にした上で, 可能な限り同じ切断面とした。さらに，塗布したワックスやオイルは 一般的に流通している自然由来のものであり，ワックスはLIBERON 社のBIVAX MEHILÄISVAHA (NEUTRAL)，オイルはLETONKINOIS 社 のBio Impression を採用し，木材の表面にムラが出ないよう均一に塗布
した。なお，全ての木材を室温 20 度，湿度 $65 \%$ の環境下で一定期間 保管し，含水率などの前提条件を揃えた上でインタビューに使用した。

注 3）各被験者への共通の教示において，専門家と非専門家で異なる立場を 設定した理由として，専門家は「木材を空間設計に使用する立場とし てのユーザー」, 非専門家は「木材による空間を使用する立場としての ユーザー」という２つの異なる立場を前提として，個別インタビュー を行ったためである。また，本稿に関わる一連の研究 7) 8) では，住空 間の設計者と使用者それぞれの立場から，木材利用や木質空間設計に 関わるニーズを集約することを意図しているためである。

注 4）本稿におけるフィンランドの専門家と非専門家に対する個別インタビ ューは, 英語で行った。ただし，インタビュー中に被験者が英語で表 現しきれない語彙などがある場合は, 円滑にインタビューを進めるた め, 一旦フィンランド語での発言を許可し, 後で被験者とフィンラン ド語による語彙の意味を英語に訳して確定させるように配慮した。こ れは, 英語とフィンランド語の間での語彙の意味の損失を可能な限り 少なくすることで, 被験者自身の言葉を最大限, 尊重するためである。

注 5）被験者の各属性における評価項目の指摘回数の集計では，1人の被験 者が複数回指摘した項目も 1 回として集計した。これは, 項目によって, 1 人の被験者のみで多数回指摘している項目がみられ，そのまま被験 者の属性毎の指摘回数として集計した場合, 1 人の被験者の指摘回数 が最終的な結果に及ぼす影響が大きいと判断したためである。

注 6） 4 名の著者の合議によって評価項目の意味内容の類似性をもとに各項 目を統一した。続いて, 各項目を意味内容によってまとめていくことで, 小分類を得た。さらに, 各小分類を包括するグループによってまとめ, 大分類を得た。各項目の最終的な分類は，大分類と小分類によって決 定される。なお，各項目の意味内容や分類を決定する際，判断が分か れる項目は，判断の根拠を著者全員で議論し，全員の合意が得られた 時点で再び全ての項目の分類を行った。最終的に全ての項目について 判断が一致するまで分類や意味内容の決定を繰り返し行った。

注 7） 3.2 節以降において, 各属性の分析を行う際, 特に断りのない限り, 学 生, 一般人, 建築家, インテリアデザイナーの順に分析結果を記載する。

注 8） 5 名以上が指摘した評価項目は，一定以上の被験者が指摘した項目か つ, 相反する評価項目や複数の評価項目と多様な繋がりを示した項目 であった。よって, 本稿においても, 評価構造に潜在する共通点や相 違点を考察する際，5名以上が指摘した項目を用いて分析を行った。

注 9）前稿 ${ }^{8}$ では, 軸の解釈に用いる項目を選定する際, カテゴリースコア が絶対值 1 以上の項目をもとに各軸の解釈を行った。しかし, 本稿では, 得られた全評価項目数が前稿 ${ }^{81}$ に比べて 1.5 倍以上となり, カテゴリ 一スコアが絶対值 1 以上の項目を基準とすると, 該当する項目数が多 く, 評価構造もより複雑化して解釈が困難であった。よって, 本稿では, カテゴリースコアが絶対值 1.5 以上の項目をもとに軸の解釈を行った。

注 10）評価項目に基づく数量化而類分析を行う際，前稿 ${ }^{81}$ と同様に，木材の 特徵や性質，木材を用いた空間の特徵，心情や感情に関わる階層性を もった項目を区別することなく分析を行った。また，他の軸と類似し た項目が含まれる場合も存在するが，各軸の正負それぞれに含まれる 項目の関係, 各軸における正負両側の関係を考慮して軸の解釈を行っ た。さらに, 最終的な各軸の名前を決定づける際, 木材の性質に加えて, 同じ軸の正負において因果関係のみられた心情や感情，空間の特徴な どに関する項目も考慮して決定した。

\section{参考文献}

1) The World Bank: Forest area (\% of land area), 2015

2) J ussi Tiainen:Wood A rchitecture in Finland, Rakennustieto Publishing, 2008.3

3) Markku Karjalainen:The status of wood construction in Finland, M inistory of Employment and the Economy, 2014.8

4) Finnish Innovation Fund Sitra, VTT Technical Research Centre of Finland, Tekes: World-class sustainable solutions from Finland Helsinki, 2011

5) M arkku K arjalainen:Status and possibilities of woodconstruction in Finland, M inistory of Employment and the Economy, 2015

6) Kuismanen Kimo:INNOVATIVE USE OF WOOD IN ARCHITECTURE, OUlu, 2013.5

7）坂口大史, 柴田智菜美，坂井文也，北川啓介：内装用木材の認知構造から みる潜在的選択要因, フィンランドの設計専門家と非専門家を対象とし て，日本建築学会計画系論文集，第 715 号，pp.2021-2031，2015.9

8) 坂口大史，坂井文也，北川啓介：日本の設計専門家と非専門家の住空間 に用いる内装用木材対する評価構造, 日本建築学会計画系論文集，第 721 号, pp.581-591,2016.3 


\section{EVALUATION STRUCTURE OF FINNISH DESIGN PROFESSIONALS AND LAYMEN}

ON INTERIOR WOOD FOR LIVING SPACE

\section{Daishi SAKAGUCHI*, Kazuma ASAKURA**, Keisuke KITAGAWA *** and Fumiya SAKAI****}

* Doctoral Candidate, Graduate School of Engineering, Nagoya Institute of Technology:

Assist. Prof., Faculty of Health Science, Department of Human Care Engineering, Nihon Fukushi Univ., Master of Engineering ** Okumura Corporation, Master of Engineering

*** Assoc. Prof., Tsukuri College, Graduate School of Engineering, Nagoya Institute of Technology, Doctor of Engineering **** Kisogawa-Joryu River Office, Chubu Regional Bureau, Ministry of Land, Infrastructure and Transport, Master of Engineering

\section{Introduction}

In a previous study, the evaluation structure of Japanese design professionals and laymen for interior wood were investigated. In consequence, 4 types of evaluation structures and the tendency of the evaluation were revealed. Following the study, the tendency of the evaluation of Finnish design professionals and laymen for interior wood were investigated through the analysis of the evaluation structure in this study.

\section{Material \& Method}

This study also included 12 different wood samples (4 different species: Finnish spruce: Picea abies, Finnish pine: Pinus sylvestris, and heartwood and sapwood of Japanese cedar: Cryptomeria japonica and 3 different finishing: plain surface, wax coating and oil finishing). This research was also conducted using evaluation grid method. As a first step, 40 participants (10 people each from architect, interior designer, normal worker and student) divided wood samples into 5 groups according to their preference of the interior wood for living space. Following that, each group was evaluated and the factors for the evaluation was asked until the participants stopped answering. From the result of the interview, 7 core categories and 33 detailed categories were obtained as the evaluative elements. These elements were analyzed by mathematical quantification theory class III and cluster analysis. Based on the result of the analysis, the evaluation structures were investigated.

\section{Result \& Discussion}

According to the result from cluster analysis, 5 clusters were obtained. The $1^{\text {st }}$ and $5^{\text {th }}$ cluster were consisted of design professionals. In the $1^{\text {st }}$ cluster, the needs for characteristic and adaptive wood to surroundings were observed. The feature in $5^{\text {th }}$ cluster was seen as originality and functionality of wood. On the other hand, the $2^{\text {nd }}$, $3^{\text {rd }}$ and $4^{\text {th }}$ cluster were by laymen. In the $2^{\text {nd }}$ cluster showing the tendency of normal worker, the feature was regarding familiarity and harmony of wood. In the $3^{\text {rd }}$ cluster mainly consisted of students, the students evaluate ordinariness and visual aspect of wood. The feature of $4^{\text {th }}$ cluster common in the laymen was ordinariness and physical aspect of wood.

As a result, the tendency of the evaluation structure was clearly divided by the design professionals and laymen in case of Finland. The features of the structure for the professionals were observed as calmness by the condition of grain pattern and added value for space by natural aging and versatility of wood. The difference between architects and interior designers was that architects paid more attention to durability and quality. In addition, architects respected versatility of wood in space. On the other hand, interior designers emphasized harmony of wood with light including the natural aging aspect. Both architects and interior designers also put the value on environmental friendliness of wood. The features of the structure for the laymen were related to harmony with surroundings by familiarity of wood, modernity by novel color and safety by naturalness of wood. The feature of the evaluation structure by the students was on novelty of wood by visual aspect. The normal workers, on the contrary, required comfortability by the harmony and familiarity.

\section{Conclusion}

Considering the difference between the professionals and laymen, 5 types of evaluation structures were revealed. The clear differences were seen in the structures of the professionals and laymen. In a future study, a comparative study on the evaluation structure of Japanese and Finnish design professionals and laymen will be conducted to examine the effective measures for utilization of domestic wood and guideline to design wooden architecture. 